\title{
PERAN PENDIDIK PAUD DALAM MEMBANGUN KARAKTER ANAK
}

\author{
Oleh: \\ Ika Budi Maryatun \\ PAUD FIP Universitas Negeri Yogyakarta \\ ika_budimaryatun@uny.ac.id
}

\begin{abstract}
Abstrak
Artikel ini bertujuan untuk menjabarkan peran pendidik PAUD dalam membangun karakter anak sejak dini di lembaga. Lembaga pendidikan anak usia dini (PAUD) terdiri dari TPA, KB, dan TK. Pendidik PAUD yang dimaksud adalah guru dan pengasuh di sekolah, baik formal maupun nonformal. Karakter yang dikembangkan mengacu pada perkembangan moral anak melalui tiga pendekatan penanaman moral Lickona, yaitu konsep moral, sikap moral, dan prilaku moral. Peran pendidik dalam membangun karakter anak sejak dini meliputi empat hal, yaitu (1) pendidik sebagai pendidik, (2) pendidik sebagai panutan, (3) pendidik sebagai perancang pengembangan, dan (4) pendidik sebagai konsultan dan mediator.
\end{abstract}

Kata Kunci: Pendidik PAUD, Karakter Anak

\begin{abstract}
The article is aimed at describing the role of early childhood teachers in developing students' characters earlier in the institution. The early childhood education (PAUD) institution includes TPA (children day care program), KB (play group), and TK (kindergarten). The term 'teacher' here covers teachers and care-takers in either formal or informal schools. The characters developed refer to the moral development of children through Lickona's three moral development approaches: moral concept, moral attitude, and moral behavior. The teachers' roles in developing the early-aged children comprises four ideas namely 1) teacher as source of information, 2) teacher as a role-model, 3) teacher as a development designer, and 4) teacher as a consultant and mediator.
\end{abstract}

Keywords: teachers of early-aged students, students' character

\section{PENDAHULUAN}

Usia dini merupakan usia dimana yang tepat untuk diberikan berbagai konsep kehidupan sebagai bekal di kehidupan selanjutnya. Semenjak seorang manusia lahir dari rahim ibu sampai ia dapat hidup mandiri memerlukan waktu yang sangat panjang dibanding dengan makhluk hidup lainnya (Bronowski:1973). Anak mempunyai lebih kurang 100 milyar sel otak sejak lahir. Sel-sel otak tersebut membutuhkan stimulasi yang tepat agar dapat saling terhubung menjadi jalinan yang padat sebagai tanda seorang anak cerdas. Stimulasi pendidikan yang diberikan dan pola asuh orang tua serta pendidik merupakan salah satu penentu bagi pengoptimalan penggunaan otak ini.

Berdasarkan hasil penelitian Osbon, White, dan Bloom (2004), di bidang Neurologi, ditemukan fakta bahwa perkembangan kecerdasan anak mencapai $50 \%$ pada usia $0-4$ tahun, $80 \%$ pada usia 4-8 tahun, dan $100 \%$ pada usia 8-18 tahun. Sedangkan pertumbuhan fisik anak usia 0 tahun mencapai $25 \%$, 6 tahun 
mencapai $90 \%$, dan 12 tahun mencapai $100 \%$. Oleh karena itu, usia dini bagi seorang anak merupakan masa yang strategis bagi perkembangan hidup selanjutnya.

Mengacu pada hasil penelitian di atas, maka pemberian stimulasi pendidikan yang tepat perlu diperhatikan. Pendidikan anak usia dini memberikan stimulasi bagi pengembangan enam aspek perkembangan yang ada pada anak yang terangkum dalam menu generik pembelajaran PAUD. Salah satu aspek yang menjadi perhatian pengembangan adalah aspek moral dan nilai-nilai agama. Aspek moral mencakup pada aspek kehidupan keagamaan, nilai, dan karakter anak. Karakter yang akan dibahas lebih jauh dihubungkan dengan karakter bangsa yang dikembangkan pada anak sejak dini agar menjadi budaya yang mengakar pada jiwa anak.

Pemberian stimulasi aspek yang akan dikembangkan, terutama karakter yang bisa menjadi sangat abstrak bagi anak, harus mengguna metode yang tepat. Penyampaian cara yang benar akan memungkinkan terwujudnya pembiasaan sebagai perilaku terhadap karakter yang akan ditanamkan. Karakter akan menjadi jiwa anak, jika dalam penyampaiannya menyenangkandan menantang untuk dipelajari bagi anak, baik pemberian pengetahuan maupun pada penanaman tingkah laku.

\section{PENDIDIKAN ANAK USIA DINI}

\section{Pendidik}

UU No. 20 tahun 2003 pada 39 ayat 2 menjabarkan bahwa pendidik adalah tenaga profesional yang bertugas merencanakan dan melaksanakan proses pembelajaran, menilai hasil pembelajaran, melakukan pembimbingan dan pelatihan, serta melakukan penelitian dan pengabdian kepada masyarakat, terutama bagi pendidik pada perguruan tinggi. Sementara pada pada pasal 1 bagian BAB 1 dijelaskan mengenai tenaga kependidikan yaitu orang yang berkualifikasi sebagai guru, dosen, konselor, pamong belajar, widyaiswara, tutor, instruktur, fasilitator, dan sebutan lain yang sesuai dengan kekhususannya, serta berpartisipasi dalam menyelenggarakan pendidikan.

Dari pengertian di atas dijelaskan bahwa tenaga pendidik tidak hanya guru, melainkan semua pihak yang terlibat dalam penyelengaraan pendidikan. Namun untuk dapat dikatakan sebagai pendidik haruslah mampu merencanakan, melaksanakan, menilai, melakukan pembimbingan dan pelatihan dalam pembelajaran. Jika merujuk pada kegiatan yang harus dilakukan seorang pendidik, maka yang dikatakan sebagai pendidik hanya guru dan orang tua.

\section{Pendidikan Anak Usia Dini}

Pendidikan anak usia dini merupakan penjabaran dari sebuah pendidikan yang bermula dari seluruh negara di dunia yang dalam bahasa Inggrisnya disebut dengan early childhood education (ECD). Menu generik menjabarkan pendidikan anak usia dini (PAUD) sebagai suatu upaya pembinaan yang ditujukan kepada anak sejak dini yang dilakukan melalui pemberian rangsangsangan pendidikan untuk membantu pertumbuhan dan perkembangan jasmani dan rohani agar anak memiliki kesiapan dalam memasuki pendidikan dasar dan kehidupan tahap selanjutnya (2007 : 3). PAUD merupakan lembaga terdekat dengan kehidupan anak yang sangat mempengaruhi kehidupan dan tingkah laku anak hingga dewasa. Keluarga merupakan lembaga PAUD yang paling dekat dengan kehidupan anak. Keluarga akan mempengaruhi kehidupan bersosial anak di sekolah baik bersama guru maupun teman sebayanya (Feeney.,et.al, 2007 : 29).

$$
\text { PAUD juga dapat dikatakan }
$$
sebagai proses pembinaan tumbuh kembang anak usia 0-8 tahun secara menyeluruh, mencakup aspek fisik dan 
nonfisik dengan memberikan rangsangan bagi Perkembangan mental, intelektual, emosional, moral, dan sosial (NEST, 2007). Seluruh aspek perkembangan anak dikembangkan melalui program PAUD ini dalam aktivitas belajar yang menyenangkan karena dilaksanakan dalam kegiatan bermain. Aspek perkembangan sebagai potensi bawaan anak tidak akan berkembang tanpa stimulasi dari orang tua di rumah dan pendidik anak di sekolah. PAUD merupakan peletak dasar berbagai perkembangan anak yang akan sangat berpengaruh pada proses kehidupan anak di masa mendatang.

\section{Pendidik PAUD}

Pendidik PAUD, jika mengacu pada dua pengertian sebelumnya tentang pendidik dan PAUD merupakan orang yang bertanggung jawab merencanakan, melaksanakan, menilai, melakukan pembimbingan dan pelatihan dalam pembelajaran pada anak usia 0-8 tahun secara menyeluruh. Pendidik pada PAUD mempunyai tugas yang lebih kompleks daripada pendidik pada tingkat pendidikan di atasnya. Hal ini dikarenakan PAUD merupakan tingkat pendidikan yang paling mendasar sebagai pondasi bagi pendidikan selanjutnya.

Pondasi yang dibangun di PAUD menuntut struktur yang kuat, baik aspek pembelajaran dalam kegiatan main maupun pengembangan potensi anak. Konsep akan ternaman jika pendidik mampu menciptakan program stimulasi yang menarik untuk diikuti dalam kegiatan. Karenanya seorang pendidik PAUD dituntut mampu merancang kegiatan yang menarik dan menantang, melaksanakan pembelajaran yang menyenangkan, dapat mengamati dan mencatat proses tumbuh kembang anak didiknya, dan mengevaluasi program kegiatan main atau pembelajaran yang telah dilakukannya.

\section{PENDIDIKAN KARAKTER}

\section{Karakter dan Moral}

Karakter seperti dijabarkan oleh Puskur dalam Pengembangan Pendidikan Budaya dan Karakter merupakan watak, tabiat, akhlak, atau kepribadian seseorang yang terbentuk dari hasil internalisasi berbagai kebajikan (virtues) yang diyakininya dan digunakannya sebagai landasan untuk cara pandang, berpikir, bersikap, dan bertindak (2010 : 3). Berbicara tentang karakter, maka akan menyangkut semua aspek perkembangan yang dimiliki seorang anak. Karakter harus ditanamkan dalam setiap lini kehidupan anak agar dapat menjadi kepribadiannya kelak.

Karakter bangsa Indonesia lebih pada pembiasaan perilaku sebagai warisan luhur nenek moyang, salah satunya adalah aspek Moral dan Nilai-nilai Agama. Moral dasar yang dikembangkan pada anak ada sekitar 16 unsur sebagai dasar penanaman karakter meliputi kepedulian dan empati, kerjasama, berani, keteguhan dan komitmen, adil, suka menolong, kejujuran dan integritas, humor, mandiri dan percaya diri, loyalitas, sabar, rasa bangga, banyak akal, sikap respek, tanggung jawab, serta toleran (Schiller \& Bryant, 2002).

Perkembangan moral Kohlberg secara runtut dijabarkan meliputi tiga tahap, yaitu preconventional, conventional, dan praconventional (Berk, 2008). Tahap preconventional, banyak terjadi pada anak di bawah enam tahun. Pada tahap ini, perilaku anak hanya dipengaruhi oleh konsekuensi fisik. Anak belum menunjukkan internalisasi nilainilai moral dalam hidupnya. Sesuatu dianggap benar dan baik jika menghasilkan hal yang menguntungkan dan menyenangkan secara fisik pada dirinya. Artinya, anak berperilaku bukan karena sadar pada norma dan etika lingkungan masyarakat, tetapi lebih pada takut dimarah oleh ibu atau untuk mendapat pujian.

Yang kedua adalah tahap conventional, dimana anak berperilaku 
untuk memperoleh suatu predikat, seperti anak baik, anak ganteng, anak pintar dan sebagainya. Tetapi di tahap kedua ini anak mulai sadar akan adanya suatu aturan dalam masyarakat. Aturan sederhana yang dipahami anak misalnya tidak buang air kecil di depan pintu. Tahap ketiga yaitu postconventional, dimana anak sudah dapat memilih sendiri aktivitasnya dan mampu mempertanggungjawabkan pilihan tersebut.

Memahami ketiga tahapan perkembangan moral di atas, dapat digunakan sebagai acuan dalam menyusun rencana pembiasaan perilaku yang akan ditanamkan sebagai proses membangun karakter. Proses penanaman karakter ini tidak boleh jauh dari prinsip perkembangan yang ada pada anak usia ini.

\section{Pendekatan Penanaman Karakter Anak Usia Dini}

Pendidik anak usia mempunyai tugas yang sangat kompleks dalam menghadapi anak yang masih dalam usia muda. Tugas mendidik anak usia dini tidaklah muda, karena anak belajar dari apa yang dilihat, didengar, dan dirasakannya. Sebelum meminta anak berperilaku moral yang baik, terlebih dahulu pendidik PAUD memiliki perilaku postif yang dapat dilihat dan ditiru anak. Sementara pendidikan moral selama ini yang dilakukan di sekolah lebih banyak menerapkan konsep dan teori saja. penerapan dalam bentuk perilaku masih kurang mendapat perhatian. Peran pendidik, terutama pada tingkat PAUD, tidak hanya sebagai pentransfer konsep ilmu saja, namun lebih pada pembimbing bagi pembentukan perilaku, watak hingga karakter.

Pengembangan nilai moral sebagai dasar membangun karakter anak harus memperhatikan sifat anak itu sendiri. Anak paling mudah mempelajari sesuatu jika melihat dan melakukan sendiri. Hal ini dikarenakan anak masih belajar menggunakan organ sensorinya, daripada perasaan yang umum digunakan orang dewasa. Thomas Lickona menggambar pendekatan yang digunakan untuk menanamkan nilai moral pada anak seperti terlihat pada bagan berikut (Lickona, 1993) :

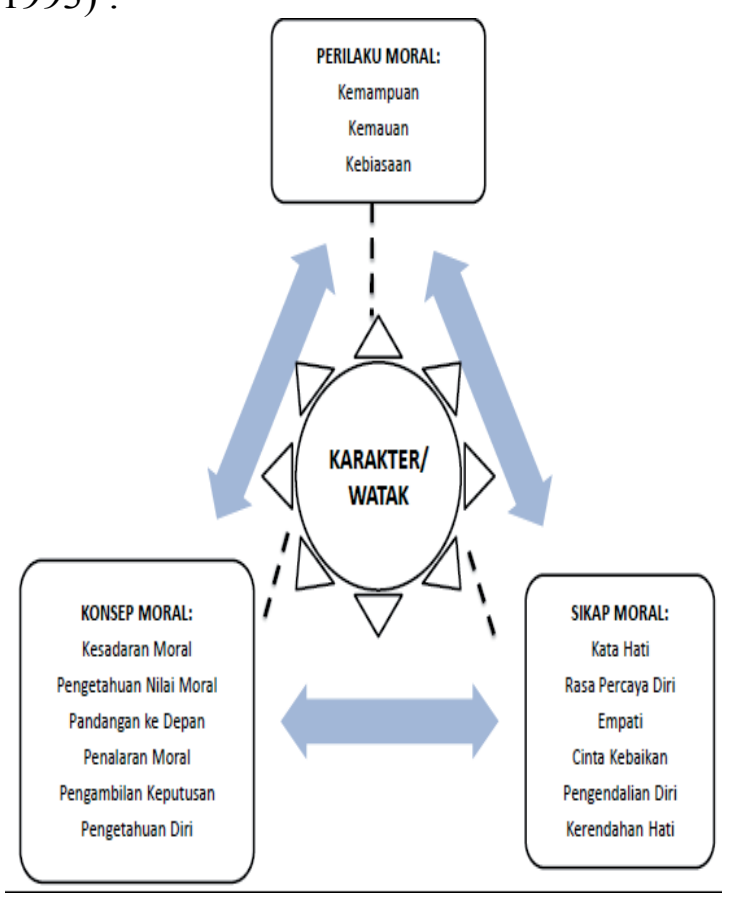

Dari bagan di atas, dapat dijelaskan bahwa pendekatan penanaman moral dengan memberikan konsep moral sebagai pengetahuan terlebih dahulu pada anak. Pemberian konsep ini tidak akan bermakna jika tidak dibarengi dengan sikap yang terwujud dalam pemikiran anak. Sikap ini pun harus diwujudkan dalam perilaku anak melalu pembiasaan yang dilakukan di rumah maupun di sekolah. Anak harus mendapat contoh konkret mengenai moral itu dalam wujud konsep, sikap, dan perilaku. Ketiga unsur ini tidak dapat dipisahkan dan diajarkan sendiri-sendiri. Setiap memberikan konsep, pendidik juga menunjukkan sikap dan beriperilaku sesuai konsep yang diajarkannya.

Pemberian konsep moral sebagai bagian karakter pada anak usia dini lebih banyak dilakukan melalui kegiatankegiatan bercerita, karyawisata, bernyanyi, dan sajak. Melalui cerita, pendidik dapat mengembangkan nilai-nilai budaya, sosial, 
agama, etos kerja, dan berbagai konsep moral lainnya agar menjadi sikap yang dapat diwujudkan dalam perilaku anak. Karyawisata merupakan kegiatan untuk memperlihatkan dunia sebenarnya agar anak memperoleh wujud dari konsep moral yang didapatnya. Bernyanyi dan sajak atau syair merupakan dua hal yang banyak terdapat kehidupan anak. Di dalam syair sajak dan lagu dapat diberikan konsep-konsep moral yang akan ditanamkan.

\section{Peran Pendidik PAUD dalam Menanamkan Karakter Anak}

Pendidik PAUD tidak hanya berperan pada aspek akademik saja. Pendidik berperan dalam hal pembelajaran (dari proses perencanaan, pelaksanaan, hingga evaluasi), berperan dalam proses administrasi kelas, dan berperan dalam psikologis anak (proses pencegahan, penanganan, hingga rehabilitasi). Pembentukan karakter anak termasuk dalam peran guru dalam bidang psikologis ini, karena guru harus mencegah muncul karakter yang buruk, menanamkan karakter yang diharapkan, dan memperbaiki karakter yang terlanjur rusak.

Penanaman karakter di sekolah membutuhkan pendidik PAUD yang dapat dijadikan tokoh sekaligus perancang dalam proses pembentukan ini. Peran pendidik PAUD dalam proses menanamkan karakter anak dapat dijabarkan sebagai berikut :

\section{a. Pendidik PAUD sebagai pendidik}

Pendidik PAUD bukan sekedar orang yang menstranfer ilmu ke anakanak, namun lebih dari itu, merupakan orng yang berperan memberikan konsep ilmu bahkan pembentukan sikap dan perilaku. Pendidik pada tingkat PAUD secara lengsung membuat rancangan pengembangan perilaku karakter pada anak, melaksanakan, dan mengembangkannya sehingga menjadi cara hidup anak.
Pendidik perlu menguasai strategi pengembangan pada anak usia dini sehingga rencana yang sudah disusun dapat dilaksanakan sesuai tujuan pengembangan. Pendidik PAUD perlu memahami karakteristik anak sesuai usia, budaya, dan lingkungannya sehingga apa yang disampaikan tidak terlalu jauh dengan kehidupan anak sehari-hari. Hal ini juga agar perilaku yang akan kita tanamkan dapat diamati dan ditiru anak sesuai sifatnya sebagai pengamat dan peniru.

\section{b. Pendidik PAUD sebagai panutan}

Pendidik PAUD adalah salah orang yang paling dekat dengan hidup anak, karenanya setiap sikap yang terlihat dari pendidik akan dicontoh anak. Anak belum mampu memilih perilaku mana yang boleh ditiru dan yang tidak. Setiap perilaku yang teramati oleh anak, dianggapnya sebagai perilaku yang boleh ditiru. Pendidik perlu memahami bagaimana bersikap dan berperilaku di depan anak-anak agar sikap dan perilaku yang dicontoh anak adalah perilaku yang diharapkan tertanam pada anak saja.

Anak paling mudah mempelajari sesuatu dari mengamati dan meniru, terutama dalam menanamkan karakter ini. Cara paling mudah menanamkan karakter adalah melalui pembiasaan perilaku yang diharapkan tersebut dalam setiap aktivitas anak. Keberhasilan pembiasaan akan menentukan keberhasilan pembentukan karakter anak yang berpengaruh pada pembentukan karakter bangsa nantinya.

\section{c. Pendidik PAUD sebagai perancang pengembangan}

Semua program rancangan pembentukan karakter perlu dirancang dengan baik oleh pendidik agar jelas tujuan dan dapat menggunakan cara yang tepat. Rancangan ini dipadukan dengan program kegiatan sehari-hari anak di sekolah dan di rumah. Materi pembiasaan yang perlu untuk dirancang meliputi 
kepedulian dan empati, kerjasama, berani, suka menolong, kejujuran dan integritas, mandiri dan percaya diri, sabar, rasa bangga, banyak akal, sikap respek, tanggung jawab, serta toleran. Semua kegiatan ini dapat dirancang dalam kegiatan yang bersifat individu maupun kelompok.

d. Pendidik PAUD sebagai konsultan dan mediator

Pendidik PAUD, terutama guru, merupakan orang yang paling benar di mata anak-anak sehingga dijadikan tempat untuk mengadukan segala kesulitan yang dialaminya. Pendidik dijadikan tempat berbagi paling aman bagi anak. Karenanya pendidik perlu memiliki kemampuan menyelesaikan permasalahan anak ketika mereka mengadu. Jika ada konflik diantara sesama anak, guru perlu mencari tahu sebab konflik tersebut sebelum menyelesaikannya. Disini akan tertanam sikap jujur, berani, dan bertanggung jawab.

\section{KESIMPULAN}

Karakter merupakan identitas suatu bangsa, karenanya perlu ditanamkan sedini mungkin agar mengakar dalam hidup seseorang sebagai warga negara. Karakter memberikan identitas yang dapat dilihat secara kasat mata. Karakter yang baik akan membawa nama baik negara juga, namun karakter yang buruk akan menghancurkan bangsa itu. Karakter harus dibiasakan dalam segala aspek kehidupan anak melalui pemberian contoh yang nanti akan melahirkan perilaku, tidak sekedar diajarkan secara teori dan lembar kerja di sekolah.

\footnotetext{
Landasan karakter tidak dibangun oleh ceramah, tetapi oleh batu-batu teladan baik yang disusun hari demi hari
}

$$
\begin{gathered}
\text { (mutiara oleh-oleh dari sebuah warung } \\
\text { mie) }
\end{gathered}
$$

\section{DAFTAR PUSTAKA}

Berk, Laura. (2008). Child Development. USA : Pearson Education

Feeny, Stephanie et.al. Who Am I In The Lives of Children?. Seven edition. USA : Merril Prentice-Hall,Inc. (2006)

Schiller, Pam \& Tamera Bryant. (2002). 16 Moral Dasar Bagi Anak. Jakarta : PT Elex Media Komputindo

NEST TEAM. 2007. Modul Perkembangan Anak untuk PPAUD. Jakarta : Dir.PAUD, Kemendiknas.

Lickona, Thomas. (1993). The Return of Character Education. (Journal of Education Leadership, vol.3/No.3?Nopember 1993).

http://www.slideshare.net/pengga wa/pendidikan-karakter-5758744

Santrock, John W. (2003). Psychology 7. USA : McGraw-Hill co,Inc

UU No. 20 tahun $\underline{2003}$

----. (2007). Kerangka Dasar Kurikulum Pendidikan Anak Usia Dini. Jakarta : Puskur.

----. (2010). Pengembangan Pendidikan Budaya dan Karakter Bangsa. Jakarta : Puskur, Kemendiknas 